\title{
Article \\ Effects of Yeast Product Addition and Fermentation Temperature on Lipid Composition, Taste and Mouthfeel Characteristics of Pinot Noir Wine
}

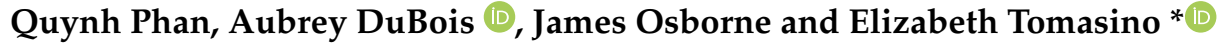

check for

updates

Citation: Phan, Q.; DuBois, A.;

Osborne, J.; Tomasino, E. Effects of Yeast Product Addition and

Fermentation Temperature on Lipid

Composition, Taste and Mouthfeel

Characteristics of Pinot Noir Wine.

Horticulturae 2022, 8, 52. https://

doi.org/10.3390/horticulturae8010052

Academic Editors: Alessandra

Durazzo and Massimo Lucarini

Received: 16 November 2021

Accepted: 5 January 2022

Published: 6 January 2022

Publisher's Note: MDPI stays neutral with regard to jurisdictional claims in published maps and institutional affiliations.

Copyright: (c) 2022 by the authors. Licensee MDPI, Basel, Switzerland. This article is an open access article distributed under the terms and conditions of the Creative Commons Attribution (CC BY) license (https:// creativecommons.org/licenses/by/ $4.0 /)$.
Department of Food Science and Technology, Oregon State University, Corvallis, OR 95331, USA; quynh.phan@oregonstate.edu (Q.P.); aubrey.dubois@oregonstate.edu (A.D.); james.osborne@oregonstate.edu (J.O.)

* Correspondence: elizabeth.tomasino@oregonstate.edu; Tel.: +1-541-737-4866

\begin{abstract}
Lipids have important impacts on wine sensory. By targeting the lipid sources in wine, mainly from grape tissues and yeast cell walls, it was possible to alter the wine lipid profile thus potentially changing the final product quality. This research examined the changes of wine total lipids, lipid composition and sensory characteristics of Pinot noir wines in response to the winemaking factors, fermentation temperature and yeast product addition. Pinot noir grapes were fermented at $16{ }^{\circ} \mathrm{C}$ and $27^{\circ} \mathrm{C}$. After fermentation, Oenolees ${ }^{\circledR}$ yeast product was added to the wines at three levels $(0 \mathrm{~g} / \mathrm{L}, 0.5 \mathrm{~g} / \mathrm{L}$ and $1.0 \mathrm{~g} / \mathrm{L})$. The six wine treatments were subjected to chemical analyses measuring total lipids and an untargeted lipidomic approach analyzing lipid composition. High temperature fermentation wines had significantly higher total lipid content. Random forest analysis distinguished the wine groups based on the 25 main lipids, including free fatty acids, acylcarnitines, diglycerides, triglycerides and phospholipids. Taste and mouthfeel characteristics of each treatment were assessed using descriptive analysis and check-all-that-apply (CATA) techniques. Multivariate analyses showed that changing fermentation temperature significantly impacted sweetness and drying perception in Pinot noir wines. Yeast product addition had nuanced effects on wine lipid profiles and sensory perception.
\end{abstract}

Keywords: lipidomic; winemaking; descriptive analysis; random forest; linear discriminant analysis

\section{Introduction}

Mouthfeel is an important aspect of wine quality but is not well understood. Studies of wine chemical contributions in mouthfeel perception have mainly focused on major constituents, such as phenolics, polysaccharides, proteins, ethanol, sugar, and acids [1-5]. However, there are other compositional elements that may influence perception of wine mouthfeel and taste [6,7]. Altering wine mouthfeel and taste qualities during winemaking processes may result in positive outcomes in consumers' acceptance and preference of wines $[4,8]$.

This study was focused on winemaking practices that could potentially impact wine lipids and wine taste and mouthfeel perception. Lipids are minor constituents with a concentration reported to be less than $0.1 \%$ in commercial Pinot noir wines [9]. There are two main sources of wine lipids: grape tissues and yeast cell wall [10]. Previous work has demonstrated lipids contribute to taste and mouthfeel perception in model wine solutions [7]. Consumer perception of viscosity was shown to increase significantly when a phospholipid product was added to model wines [7]. Real wine matrices are much more complex than model wine solutions and the increased complexity may alter the effects of lipids on taste and mouthfeel. Therefore, it is important to study the roles of lipids in a real wine system to further understand how wine lipids affect wine taste and mouthfeel characteristics. This study evaluated lipids in real wine, attempting to alter the 
composition using processing aids. By evaluating lipids in wine, it is possible to see if the low composition of lipids can influence taste and mouthfeel, which is normally driven by more major compositional aspects of wine. It is most likely that the smaller compositional wine aspects will cause the more nuanced changes to mouthfeel that are regularly described, but are not linked to a specific compound.

Pinot noir wines are known to contain low concentrations of tannins and polyphenolic compounds compared to other red wines [11]. These compounds are highly correlated with the astringency mouthfeel attribute in red wine [12]. Pinot noir is an ideal wine for investigating non-astringent mouthfeel compounds due to its lower tannin concentration, as the low concentration of lipids may be able to alter or overcome the mouthfeel aspects attributed to phenolic compounds. In addition, Pinot noir is a flagship varietal of Oregon, dominating the premium and ultra-premium market [13]. Understanding the factors that could maintain or improve Pinot noir wine quality is important due to the many challenges that face winemakers each year.

Changes in winemaking procedures may lead to changes in the quality of the final product [14-17]. Unterkofler et al. (2020) listed fermentation as one of the most critical value-adding steps in the entire winemaking process [17]. Fermentation temperature is an important factor that determines the quality of the final wine. Environmental temperature is known to influence the lipid composition of yeast cells [18]. Yeasts have the ability to adapt to environmental stress, such as changes in osmotic pressure, $\mathrm{pH}$, nutrient levels, exposure to heat or cold shock, high ethanol concentration or toxic compounds $[19,20]$. Lower fermentation temperatures can increase the total lipid content, total fatty acids, triacylglycerols and phospholipid content of yeast cells while diacylglycerols, free fatty acids, sterols and sterol ester concentrations remain unaffected [18]. To date, studies investigating fermentation temperature impacts on wine mouthfeel have focused only on phenolic compounds and not lipid contents of the wine [21,22]. In this study, lipid profiles, chemical components and sensory analysis of wines produced under different fermentation temperatures was performed to determine if fermentation temperature could influence the lipid content and sensory characteristics of wine.

The addition of external yeast products was also considered as yeast products contain several lipids and are commonly used in winemaking [23,24]. Many commercially-available yeast products claim to impart positive taste and mouthfeel characteristics onto the wine, as a way of altering quality post-harvest.

Yeast cell walls mainly consist of polysaccharides (mannoproteins, b-glucan, and chitin) [25]. In addition, lipids are critical components of yeast cell membranes with the concentration varying from less than 5\% dry weight to higher than $15 \%$ dry weight depending on the species [26]. Lipids play important roles in the maintenance of yeast cell structure and controlling the growth rate [27]. The present study aims were to determine the impacts of adding different concentrations of a lipid source and the relationship between lipid additions and fermentation temperatures on the chemical and sensory characteristics of wine. Understanding these relationships could provide winemakers with additional options to achieve their desired wine quality.

\section{Materials and Methods}

\subsection{Chemicals}

A mixture of lipid standards (Splash ${ }^{\circledR}$ Lipidomix ${ }^{\circledR}$ Mass Spec Standard) was purchased from Avanti Polar Lipids, Inc. (Alabaster, AL, USA). Potassium chloride (KCl) ACS reagent grade was from EMD Chemicals Inc. (Gibbstown, NJ, USA). Sodium hydroxide (NaOH) was from Sigma-Aldrich (St. Louis, MO, USA). Dichloromethane (DCM) was from EMD Millipore Corporation (Burlington, MA, USA). 2-propanol (IPA) HPLC grade, methanol $(\mathrm{MeOH}) \mathrm{HPLC}$ grade, and chloroform $\left(\mathrm{CHCl}_{3}\right)$ HPLC grade were from Fisher Chemical (Fair Lawn, NJ, USA). Milli-Q water was obtained from a Millipore Continental water system (EMD-Millipore, Billerica, MA, USA). Potassium metabisulfite was sourced from Institut Enologique de Champange (Mardeuil, Grand Est, France). 


\subsection{Winemaking}

A winemaking plan was designed to study the interactions and effects of temperature and concentration of yeast product additions on lipid composition of Pinot noir wines. Pinot noir wines were made from $V$. vinifera $\mathrm{cv}$. Pinot noir grapes harvested from Oregon State University's Woodhall Vineyard (Monroe, OR, USA) in September 2019. Wines were processed at Oregon State University's research winery (Corvallis, OR, USA). After destemming, grapes were split equally into six jacketed tanks (AAA Metal Fabrication, Dalles, OR, USA) with temperature control systems (Watlow EZ-Zone, St. Louis, MO, USA). Approximately $60 \mathrm{~kg}$ of grapes were placed in each tank. Three tanks were randomly selected to be kept at $16^{\circ} \mathrm{C}$ and the other three were maintained at $27^{\circ} \mathrm{C}$ during alcoholic fermentation. Fermaid $\mathrm{K}^{\mathrm{TM}}$ (Lallemand Oenology, Montreal, Canada) was added at a rate of $0.4 \mathrm{~g} / \mathrm{L}$. An addition of $50 \mathrm{mg} / \mathrm{L}$ of $\mathrm{SO}_{2}$ (as potassium metabisulfite) was added to all the tanks and mixed. After 20 min, Saccharomyces cerevisiae ZYMAFLORE ${ }^{\circledR}$ F15 (Laffort USA, Petaluma, CA, USA) was then added at a rate of $0.25 \mathrm{~g} / \mathrm{L}$ after hydration according to the manufacturer's specifications. Alcoholic fermentation was monitored by changes in degree Brix over time using a digital densitometer (Anton Paar, Santner Foundation, Graz, Austria) (Figure S1).

At the completion of fermentation, treatments were pressed at $0.1 \mathrm{MPa}$ for $5 \mathrm{~min}$ and the wine was dispensed into five-gallon $(18.9 \mathrm{~L})$ glass carboys and kept at room temperature (approximately $21^{\circ} \mathrm{C}$ ). Oenococcus oeni Lalvin VP41 $1^{\mathrm{TM}}$ (Lallemand Oenology, Montreal, Canada) was inoculated at approximately $1 \times 10^{6} \mathrm{cfu} / \mathrm{mL}$ to induce malolactic fermentation (MLF) following manufacturer's instructions. After MLF (malic acid less than $100 \mathrm{mg} / \mathrm{L}$ as measured by enzymatic assay (Vintessential, Victoria, Australia), the yeast product Oenolees ${ }^{\circledR}$ (Laffort USA, Petaluma, CA, USA) was added to wines at two concentrations (low concentration at $0.5 \mathrm{~g} / \mathrm{L}$ and high concentration at $1.0 \mathrm{~g} / \mathrm{L}$ ). The Oenolees ${ }^{\circledR}$ yeast product consisted of yeast cell walls and inactivated yeasts. The amount of yeast product addition was determined based on a preliminary study (data not shown). Controls with no yeast product addition were also obtained. After the addition of Oenolees ${ }^{\circledR}$, all treatments were kept at $16{ }^{\circ} \mathrm{C}$. Free sulfur dioxide $\left(\mathrm{SO}_{2}\right)$ was checked weekly using the aspiration method outlined by Iland et al. and $10 \%(w / v)$ potassium metabisulfite solution was added to the wines to maintain the concentration of free $\mathrm{SO}_{2}$ at $30 \mathrm{mg} / \mathrm{L}$ [28]. All treatments were performed in triplicate. After 90 days, samples from each replicate were taken for total lipids and lipidomic analyses. Replicates were then combined, sterile filtered $(0.45 \mu \mathrm{m}$ PES cartridge filter) and bottled in $750 \mathrm{~mL}$ green glass bottles sparged with nitrogen and sealed with aluminum screw cap closures (Stelvin ${ }^{\circledR}$, Amcor, Australia) for later sensory analyses. Detailed winemaking treatments are summarized in Figure 1.

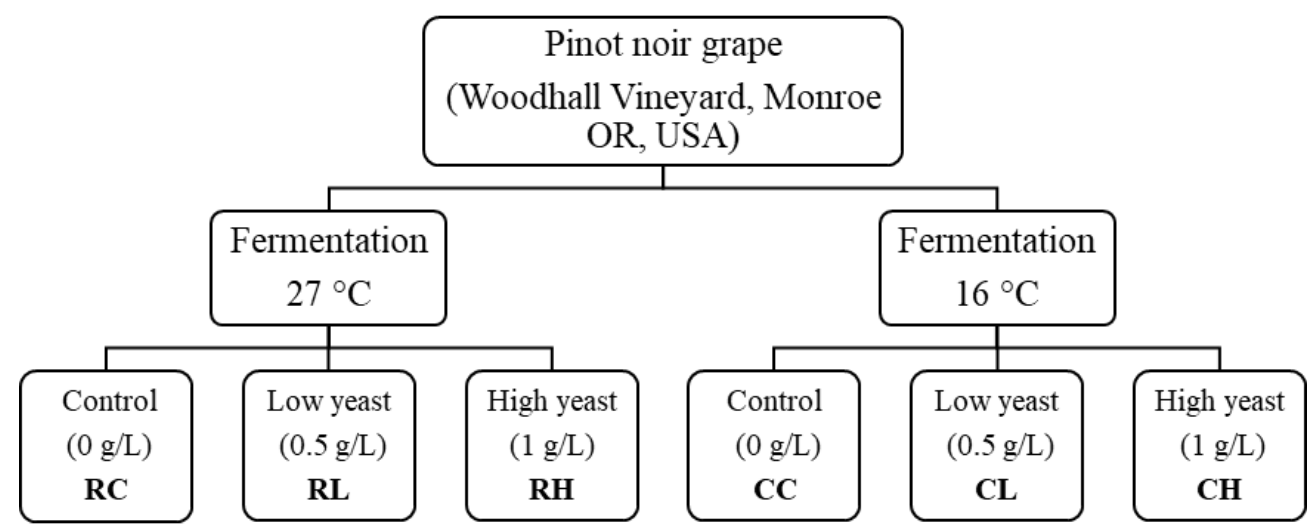

Figure 1. Pinot noir wine treatments scheme. $\left(\mathrm{RC}=\right.$ fermentation at $27^{\circ} \mathrm{C}, 0 \mathrm{~g} / \mathrm{L}$ yeast product addition; $\mathrm{RL}=$ fermentation at $27^{\circ} \mathrm{C}, 0.5 \mathrm{~g} / \mathrm{L}$ yeast product addition; $\mathrm{RH}=$ fermentation at $27^{\circ} \mathrm{C}, 1 \mathrm{~g} / \mathrm{L}$ yeast product addition; $\mathrm{CC}=$ fermentation at $16^{\circ} \mathrm{C}, 0 \mathrm{~g} / \mathrm{L}$ yeast product addition; $\mathrm{CL}=$ fermentation at $16{ }^{\circ} \mathrm{C}, 0.5 \mathrm{~g} / \mathrm{L}$ yeast product addition; $\mathrm{CH}=$ fermentation at $16{ }^{\circ} \mathrm{C}, 1 \mathrm{~g} / \mathrm{L}$ yeast product addition). 


\subsection{Basic Chemistry Analyses}

$\mathrm{pH}$ was determined by ion-selective electrode (ThermoFisher Scientific, MA, USA) and titratable acidity (TA) was measured by titration with $0.1 \mathrm{M} \mathrm{NaOH}$ [29]. Glucose/fructose, malic acid, and acetic acid were measured by enzymatic test kits (r-Biopharm, Darmstadt, Germany), while ethanol was determined using an Alcolyzer (Anton Paar, Santner Foundation, Graz, Austria). Total phenolics analysis was carried out following the Folin Ciocalteau analysis procedure [30]. Measurements were carried out in triplicate.

\subsection{Lipid Analyses}

Lipid extraction was carried out in triplicate for each treatment. A detailed procedure is described in Phan and Tomasino (2021). In summary, wine samples were concentrated and subjected to the liquid/liquid extraction method in a ratio of 1:1:0.9 $v / v$ $\mathrm{CHCl}_{3}: \mathrm{MeOH}$ :concentrated wine. The total lipids layer was extracted and pure lipids were collected after evaporating the organic solvent.

An untargeted lipidomic approach was used to obtain the lipidomic profiles of the wine samples. A solvent mixture of 25:10:65 v/v DCM:IPA:MeOH with 0.1\% (w/v) BHT was used to dissolve the total lipid extraction. Waters Acquity UPLC system (Milford, MA, USA) coupled to a quadrupole TOF mass spectrometer AB SCIEX, TripleTOF 5600 (Sciex, Concord, ON, Canada) operated in information-dependent MS/MS acquisition mode to analyze the samples. A $10 \%(v / v)$ Splash standard in $\mathrm{MeOH}$ was used as the internal standard. Lipidomic data was processed using MasterView software (AB SCIEX, Framingham, MA, USA). PeakView workstation (SCIEX, Framingham, MA, USA) was used to identify lipid compounds. Compound identification was based on the exact mass, retention time, the detection of protonated molecular ion of $\mathrm{m} / \mathrm{z}$ and the fragment ion peaks [9]. MultiQuant software (SCIEX, Framingham, MA, USA) was used to obtain peak areas. The peak area of each compound was used for semi-quantitation of relative abundancy of lipid species [31].

\subsection{Sensory Setup}

The Institutional Review Board at Oregon State University reviewed and approved this sensory study (IRB-2020-0610) at Oregon State University (Corvallis, OR, USA). The sensory panel occurred in the Arbuthnot Dairy Lab on 21 February 2021. The testing room was kept at a constant temperature of $22{ }^{\circ} \mathrm{C}$ with a stable light source consisting of both natural and artificial light. Each participant was assigned to separate white plastic booths. For all tests, $20 \mathrm{~mL}$ of sample were served at room temperature $\left(21 \pm 2{ }^{\circ} \mathrm{C}\right)$ in INAO black wineglasses (Lehmann glass, Kiyasa group, New York, NY, USA) labeled with three-digit random codes and covered with PET disposable plastic lids (Dart ${ }^{\circledR}$, Mason, MI, USA).

The wine treatments CC, CL, CH, RC, RL and RH were evaluated in duplicate. The wine samples were served in random order. Panelists were instructed to wear nose clips (Biotronics.biz, Davie, FL, USA) during the assessment. For each wine sample, panelists swished the wine around in their mouth and expectorated into a spit cup before answering the questions described in Sections 2.6 and 2.7. After finishing each sample, they were asked to rinse their palates with a $1 \mathrm{~g} / \mathrm{L}$ pectin rinsing solution in order to prevent carry-over effects from previous samples [27]. Food grade pectin was purchased from Modernist pantry (Eliot, ME, USA). Participants were required to take a one-minute break between each test.

\subsection{Panelists}

25 panelists ( 9 men, 16 women) from 21 to over 60 years old participated in this sensory study. Inclusion criteria was as follows: 21 years old or above, free of allergies to wine or wine components and were regular wine consumers (consuming on average 1 glass or more of wine per week); non-smoker; no taste deficits or other oral disorders; no piercings of the tongue, lip or cheek; and no oral lesions or canker sores. Panelists signed informed consent forms before taking the assessment. 


\subsection{Descriptive Analysis}

Panelists were instructed to evaluate sweetness, bitterness, acidity, astringency, viscosity, warmth and drying attributes on a $100 \mathrm{~mm}$ visual analog scale (VAS). The definition of each term was provided during testing and are shown in Table 1 . The $100 \mathrm{~mm}$ visual analog scales were used for rating intensity each taste and mouthfeel descriptor. The intensity ranged from none (not sweet/not bitter/not acidic/not astringent/not viscous/not warm/not dry) to extreme (very sweet/very bitter/very acidic/very astringent/very viscous/very warm/very dry).

Table 1. Definitions of the taste and mouthfeel attributes used for descriptive analysis.

\begin{tabular}{cc}
\hline Attribute & Definition \\
$\begin{array}{c}\text { Bweetness } \\
\text { and typically induced by sugar. In beverage, containing a sweet ingredient is } \\
\text { equivalent to not dry [32]. }\end{array}$ \\
$\begin{array}{c}\text { Bitterness } \\
\text { Acidity }\end{array}$ \\
$\begin{array}{c}\text { Intensity of bitter taste perceived in the mouth [33]. } \\
\text { Intringency } \\
\text { Viscosity }\end{array}$ \\
$\begin{array}{c}\text { Intensity of the acid taste perceived in the mouth [34]. } \\
\text { Drying }\end{array}$ & $\begin{array}{r}\text { Perception of body, weight, or thickness of the wine in the mouth [33]. } \\
\text { Warming effect of the mouth surfaces primarily due to alcohol [35]. }\end{array}$ \\
\hline
\end{tabular}

\subsection{Check-All-That-Apply (CATA)}

The descriptors selected for the CATA test were: irritating, grainy, plastic, sticky, greasy, watery, harsh, gummy, velvety, unripe, thin, oily, chewy and soft $[35,36]$. These attributes are associated with non-astringency mouthfeel descriptors in wine. Panelists were asked to select all terms that described the mouthfeel characteristics of each wine sample.

\subsection{Statistical Analyses}

\subsubsection{Wine Chemistry}

Two-way ANOVA and Tukey's honest significant difference (HSD) post hoc were used to compare the mean differences of total lipids, peak intensities of lipid compounds and basic wine chemistry attributes $\mathrm{pH}$, tartaric acid, glucose/fructose, acetic acid, total phenolics, and malic acid) measured in wines produced at two different temperatures and three levels of yeast product addition. The analyses were performed to examine the main effects and interaction effects of fermentation temperature and concentration of yeast product on wine lipids and other wine chemical parameters. Significance was reported at $\alpha=0.05$.

The random forest $(\mathrm{RF})$ approach and linear discriminant analysis (LDA) were used to analyze the peak intensity of all lipid compounds found in each wine sample. They were used to identify and visualize the lipid compounds important to distinguishing wines produced in different conditions: $\mathrm{CC}, \mathrm{CL}, \mathrm{CH}, \mathrm{RC}, \mathrm{RL}$ and $\mathrm{RH}$.

All statistical analyses and figures were carried out using $\mathrm{R}$ programming language [37]. The package ggplot2 was used to produce all figures [38]. R packages used for RF analysis were randomForest and varSelRF.

\subsubsection{Wine Sensory}

Two-way ANOVA was performed on the mean intensity ratings for all seven taste and mouthfeel attributes listed in Table 1 to identify the main effects and interaction effect of temperature and yeast product concentration on wine taste and mouthfeel descriptors. Correspondence analysis (CA) followed by hierarchical cluster analysis (HCA) were used to analyze CATA data [39]. FactoMineR was used for CATA analysis and factoextra for ggplot2-based elegant visualization [40,41]. 


\section{Results}

\subsection{Basic Chemistry}

Changes in fermentation temperature alone impacted wine chemical components. The basic chemistry attributes showed significant differences among wine treatments, including total phenolics, wine $\mathrm{pH}, \mathrm{TA}$ and alcohol content (Table 2). When looking at the fermentation temperature main effect, wines fermented at $27^{\circ} \mathrm{C}$ resulted in significantly higher total phenolics, lower $\mathrm{pH}$, lower TA and lower alcohol content compared to wines fermented at $16{ }^{\circ} \mathrm{C}(\alpha=0.05$, Table S1).

Table 2. Mean basic chemistry measurements of the wine treatments-mean $( \pm S E)$ with factor and interaction significance from Tukey HSD. Letters refer to Tukey groups.

\begin{tabular}{|c|c|c|c|c|c|c|c|c|c|}
\hline $\begin{array}{c}\text { Fermentation } \\
\text { Temperature }\left({ }^{\circ} \mathrm{C}\right)\end{array}$ & & 16 & & & 27 & & & $\begin{array}{c}p \text {-Value } \\
(\alpha=0.05)\end{array}$ & \\
\hline $\begin{array}{c}\text { Yeast Product } \\
\text { Concentration }(\mathrm{g} / \mathrm{L})\end{array}$ & $\mathbf{0}$ & 0.5 & 1 & $\mathbf{0}$ & 0.5 & 1 & Temp. & $\begin{array}{l}\text { Yeast } \\
\text { Product }\end{array}$ & $\underset{\text { Product }}{\text { Temp }} \times$ Yeast \\
\hline Total phenol (mg/L) & $\begin{array}{c}107.76^{\mathrm{a}} \\
(1.91)\end{array}$ & $\begin{array}{c}92.44^{\mathrm{b}} \\
(1.54)\end{array}$ & $\begin{array}{c}101.14^{\mathrm{a}, \mathrm{b}} \\
(1.71)\end{array}$ & $\begin{array}{c}138.06^{\mathrm{c}} \\
(1.96)\end{array}$ & $\begin{array}{c}135.66^{c} \\
(2.26)\end{array}$ & $\begin{array}{c}136.36^{\mathrm{c}} \\
(2.86)\end{array}$ & $<0.001 * * *$ & $0.001^{* *}$ & $0.014^{* *}$ \\
\hline $\mathrm{pH}$ & $\begin{array}{l}3.67^{\mathrm{a}} \\
(0.01)\end{array}$ & $\begin{array}{l}3.70^{\mathrm{b}} \\
(0.00)\end{array}$ & $\begin{array}{l}3.73^{\mathrm{c}} \\
(0.00)\end{array}$ & $\begin{array}{l}3.67^{\mathrm{a}} \\
(0.01)\end{array}$ & $\begin{array}{l}3.66^{\mathrm{a}} \\
(0.00)\end{array}$ & $\begin{array}{l}3.67^{\mathrm{a}} \\
(0.01)\end{array}$ & $<0.001^{* * *}$ & $0.008^{* *}$ & $0.003^{* *}$ \\
\hline Titratable acidity $(\mathrm{g} / \mathrm{L})$ & $\begin{array}{l}2.46^{a} \\
(0.01)\end{array}$ & $\begin{array}{c}2.48^{a, b} \\
(0.00)\end{array}$ & $\begin{array}{c}2.50^{b, c} \\
(0.00)\end{array}$ & $\begin{array}{l}2.46^{a} \\
(0.00)\end{array}$ & $\begin{array}{l}2.45^{\mathrm{a}} \\
(0.00)\end{array}$ & $\begin{array}{l}2.46^{a} \\
(0.01)\end{array}$ & $<0.001^{* * *}$ & $0.008 * *$ & $0.003^{* *}$ \\
\hline Alcohol $(\% v / v)$ & $\begin{array}{c}14.47^{\mathrm{a}} \\
(0.01)\end{array}$ & $\begin{array}{c}14.83^{\mathrm{b}} \\
(0.01)\end{array}$ & $\begin{array}{c}14.38^{\mathrm{a}} \\
(0.01)\end{array}$ & $\begin{array}{c}13.60^{\mathrm{c}} \\
(0.02)\end{array}$ & $\begin{array}{c}14.10^{\mathrm{d}} \\
(0.02)\end{array}$ & $\begin{array}{c}13.89^{\mathrm{e}} \\
(0.02)\end{array}$ & $<0.001 * * *$ & $<0.001 * * *$ & $<0.001^{* * *}$ \\
\hline Acetic acid (g/L) & $\begin{array}{l}0.39^{\mathrm{a}} \\
(0.03)\end{array}$ & $\begin{array}{l}0.34^{\mathrm{a}} \\
(0.01)\end{array}$ & $\begin{array}{l}0.39^{\mathrm{a}} \\
(0.01)\end{array}$ & $\begin{array}{l}0.43^{\mathrm{a}} \\
(0.07)\end{array}$ & $\begin{array}{l}0.42^{\mathrm{a}} \\
(0.02)\end{array}$ & $\begin{array}{l}0.38^{\mathrm{a}} \\
(0.03)\end{array}$ & 0.252 & 0.686 & 0.404 \\
\hline Malic acid (g/L) & $\begin{array}{l}0.07^{\mathrm{a}} \\
(0.00)\end{array}$ & $\begin{array}{c}0.06^{\mathrm{a}, \mathrm{b}} \\
(0.00)\end{array}$ & $\begin{array}{c}0.06^{\mathrm{a}, \mathrm{b}} \\
(0.00)\end{array}$ & $\begin{array}{l}0.07^{\mathrm{a}} \\
(0.00)\end{array}$ & $\begin{array}{c}0.07^{\mathrm{a}, \mathrm{b}} \\
(0.00)\end{array}$ & $\begin{array}{c}0.06^{\mathrm{a}, \mathrm{b}} \\
(0.00)\end{array}$ & 0.195 & $0.011^{* *}$ & 0.932 \\
\hline Glucose/Fructose (g/L) & $\begin{array}{l}0.56^{\mathrm{a}} \\
(0.08)\end{array}$ & $\begin{array}{l}0.63^{\mathrm{a}} \\
(0.02)\end{array}$ & $\begin{array}{l}0.58^{\mathrm{a}} \\
(0.03)\end{array}$ & $\begin{array}{l}0.70^{\mathrm{a}} \\
(0.03)\end{array}$ & $\begin{array}{l}0.65^{\mathrm{a}} \\
(0.02)\end{array}$ & $\begin{array}{l}0.62^{\mathrm{a}} \\
(0.03)\end{array}$ & 0.055 & 0.558 & 0.24 \\
\hline
\end{tabular}

** Significant at $\alpha=0.01, * * *$ Significant at $\alpha=0.001$.

Yeast product addition as a main effect showed significant impacts on wine measurements. Wines with low $(0.5 \mathrm{~g} / \mathrm{L})$ yeast product had significantly lower total phenolics compared to the control group. Significantly higher $\mathrm{pH}$, higher titratable acidity, and lower malic acid were found in wines with high $(1 \mathrm{~g} / \mathrm{L})$ yeast product addition compared to the control group (no yeast product). The three groups were distinctively different only in alcohol content, in which the low $(0.5 \mathrm{~g} / \mathrm{L})$ yeast product addition group had the highest $(14.83 \% v / v)$, followed by the control group, and the high group $(1 \mathrm{~g} / \mathrm{L})$ had the lowest ethanol $(14.38 \% v / v)$.

An interaction effect between fermentation temperature and yeast product addition was observed in total phenols, $\mathrm{pH}$, alcohol content and titratable acidity. Changes in both fermentation temperature and yeast product addition resulted in variation in the wine chemical composition.

\subsection{Total Lipids}

A significant difference $(\alpha=0.05)$ was found for the average total lipids $(\% w / w)$ in Pinot noir wines produced under two fermentation temperature conditions $16{ }^{\circ} \mathrm{C}$ and $27{ }^{\circ} \mathrm{C}$ (Table 3). Tukey's HSD showed no significant difference for the interaction of fermentation temperature $\times$ yeast product addition or no significant difference in total lipids for yeast product addition (Table 2). Wine fermented at $27^{\circ} \mathrm{C}$ resulted in higher average total lipids extraction $(0.083 \% \pm 0.006 \%)$. At $16^{\circ} \mathrm{C}$, the average total lipids extracted were $0.075 \% \pm 0.004 \%$. There were no significant differences found among the three levels of the yeast product concentration or the fermentation temperature and yeast product concentration interaction. The total lipids extracted were at the average of $0.079 \% \pm 0.005 \%$, for all yeast product addition treatments including the controls. Figure 2 shows the distribution of total lipids $(\% w / w)$ in different wine treatments. 
Table 3. Two-way ANOVA table for fermentation temperature and yeast product addition factorial experiment.

\begin{tabular}{cccccc}
\hline Source & Df & $\begin{array}{c}\text { Sum of } \\
\text { Square }\end{array}$ & Mean Square & F Value & $\operatorname{Pr}(>\mathbf{F})$ \\
\hline $\begin{array}{c}\text { Fermentation } \\
\text { Temperature }\end{array}$ & 1 & $2.827 \times 10^{-8}$ & $2.827 \times 10^{-8}$ & 10.014 & 0.00815 \\
Yeast Product Addition \\
$\begin{array}{c}\text { Fermentation } \\
\text { Temperature } \times \text { Yeast } \\
\text { Product Addition } \\
\text { Residuals }\end{array}$ & 2 & $1.600 \times 10^{-10}$ & $8.000 \times 10^{-10}$ & 0.028 & 0.97225 \\
* & 12 & $3.650 \times 10^{-9}$ & $2.827 \times 10^{-9}$ & 1.001 & 0.39612 \\
\hline Significant at $\alpha=0.05$ & & & & &
\end{tabular}

*Significant at $\alpha=0.05$.

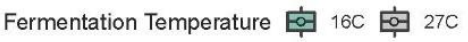

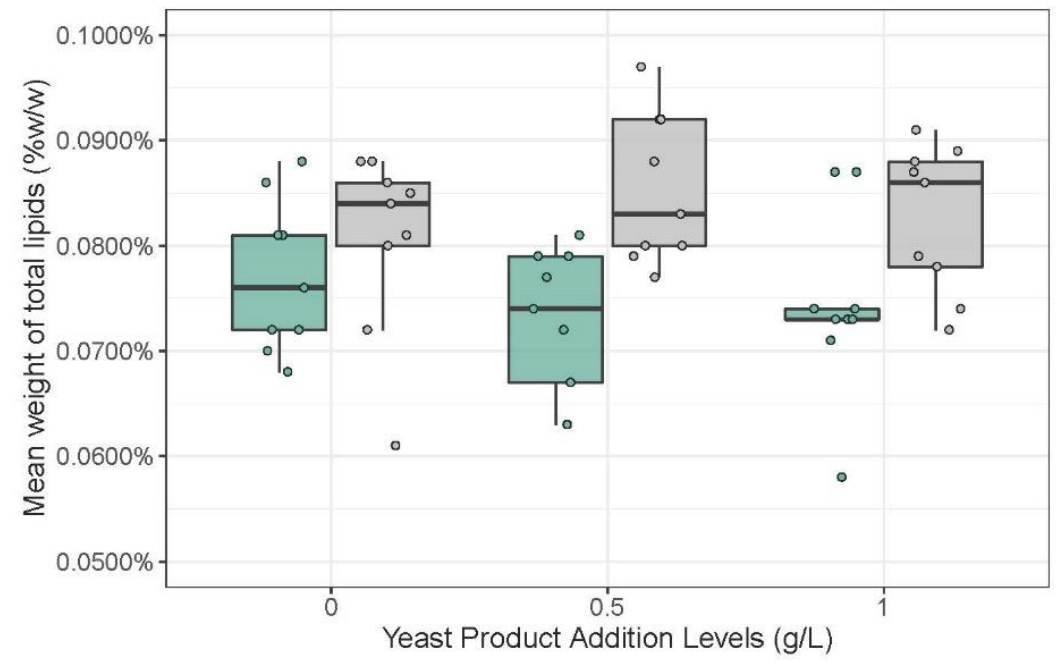

Figure 2. Boxplot of the mean of total lipids extracted from Pinot noir wines produced at two different fermentation temperatures $\left(16^{\circ} \mathrm{C}\right.$ and $\left.27^{\circ} \mathrm{C}\right)$ and three yeast product concentrations $(0 \mathrm{~g} / \mathrm{L}, 0.5 \mathrm{~g} / \mathrm{L}$, and $1 \mathrm{~g} / \mathrm{L})$.

\subsection{Lipid Profiles}

There were 13 lipid classes detected in the wine samples. A total of 233 individual lipids were identified from the extracts of the 54 Pinot noir wine samples (6 treatments $\times 3$ wine treatment replicates $\times 3$ lipid extraction replicates). Of the 233 identified lipids, 142 lipid species were found to have significant differences in peak intensities among the wines that fermented at different temperatures; 127 lipids species were found to have significant differences in peak intensities among the wines that had different levels of yeast product addition. The interaction between fermentation temperature and yeast product concentration had a significant impact on 101 lipids $(\alpha=0.05$, Table S2).

Lipid species that had the highest peak areas belong to the following three lipid classes: TG, PC and FFA (Table S3. Overall, TG with unsaturated 12, 14, 16 and/or 18 carbon chains had the greatest peak areas. The identified peaks belong to TG(14:0_18:1_18:2) combined with TG(16:0_16:1_18:2), TG(16:0_18:2_18:3), TG(16:0_16:0_18:31) and TG(12:0_14:0_18:1) combined with TG(12:0_16:0_16:1). The high peak areas for TG with carbon lengths from 12 to 18 were found among all six wine groups. In the PC class, major identified compounds were PC 38:1, PC 42:4, and PC(18:0_22:4). The mean peak areas of FFA 22:0, FFA 16:0 and FFA 18:1 were the highest. See Table 4 for lipid abbreviations and classification names. 
Table 4. Abbreviations for each lipid class found in the Pinot noir wines.

\begin{tabular}{cc}
\hline Lipid Class Name & Abbreviation \\
\hline Phosphatidylcholine & PC \\
Diglyceride & DG \\
Phosphatidylethanolamine & PE \\
Free fatty acids & FFA \\
Triglycerides & TG \\
Acylcarnitine & AC \\
Monoglycerides & MG \\
Lysophosphatidylcholine & LPC \\
Phosphatidic acids & PA \\
Lysophosphatidylethanolamine & LPE \\
Cholesteryl esters & CE \\
Phosphatidylserines & PS \\
Phosphatidylglycerols & PG \\
\hline
\end{tabular}

Figure 3 shows the total number of detected lipid compounds in each lipid class in Pinot noir wine based on a nontargeted lipidomic strategy and the number of important lipid compounds within each class selected by the random forest method. The selected lipid compounds were identified as important variables in differentiating wine treatments. DG had the highest number of important lipids, follow by FFA and TG. PC, MG, LPC, LPE, CE, PS and PG classes did not have lipid compounds important to distinguishing wines produced under the study conditions. The selected model with 25 lipid compounds showed high \% variation in linear discriminant analysis (84.29\%). Details of model selection and names of all 25 lipid compounds selected can be found in supplementary data Table S4.

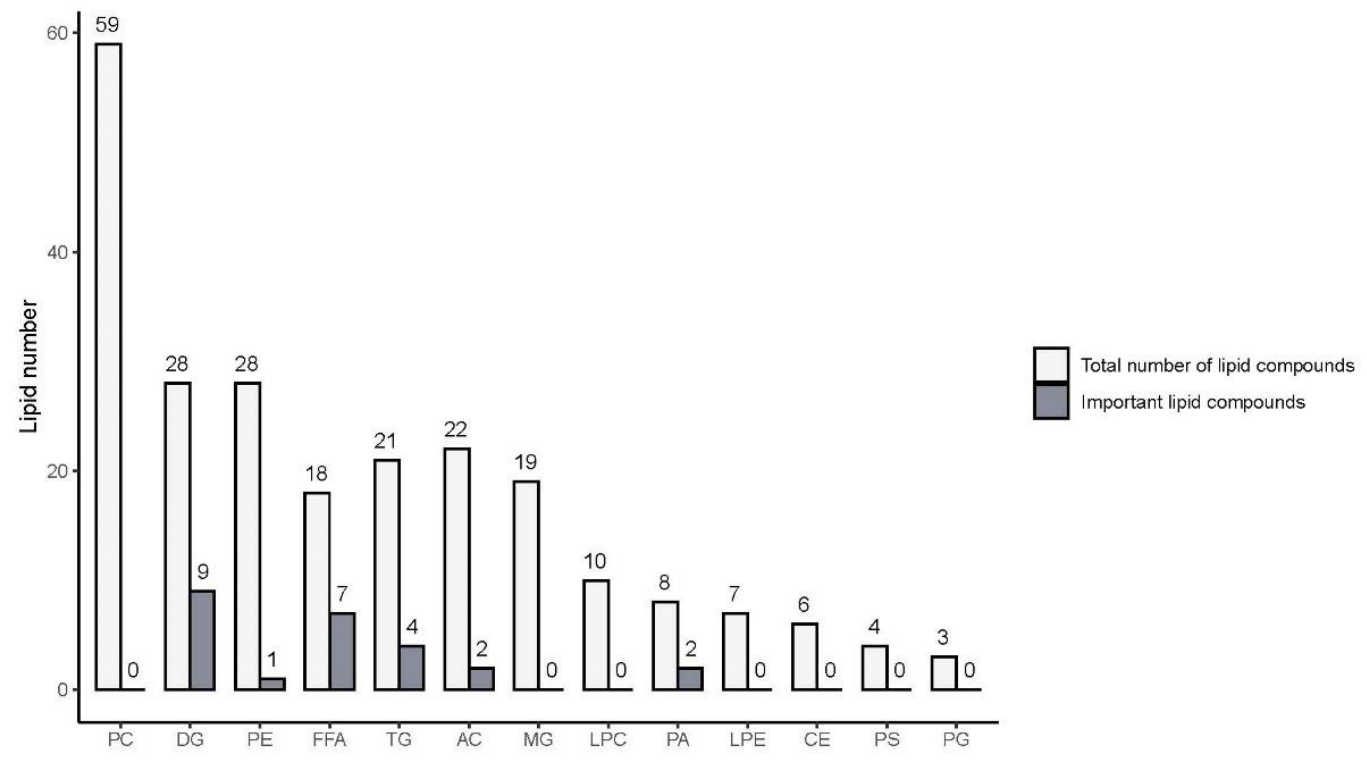

Figure 3. Total number of detected lipid compounds in each lipid class in Pinot noir wine based on a nontargeted lipidomic strategy $(\square)$ and number of important lipid compounds within each class selected by random forest method $(\square)$. See Table 3 for lipid classification names.

Linear discriminant analysis using peak areas of 25 lipid compounds and 95\% confidence intervals separated wine samples into six distinct groups based on winemaking treatments (Figure 4). The first two linear combinations explain $84 \%$ of the variance, showing a strong discrimination of wine treatments based on lipidomic data. LD1 clearly separated the wines from $16^{\circ} \mathrm{C}$ fermentation and $27^{\circ} \mathrm{C}$ fermentation. LD2 separated the high concentration of yeast addition from the control and low yeast product concentration groups. 


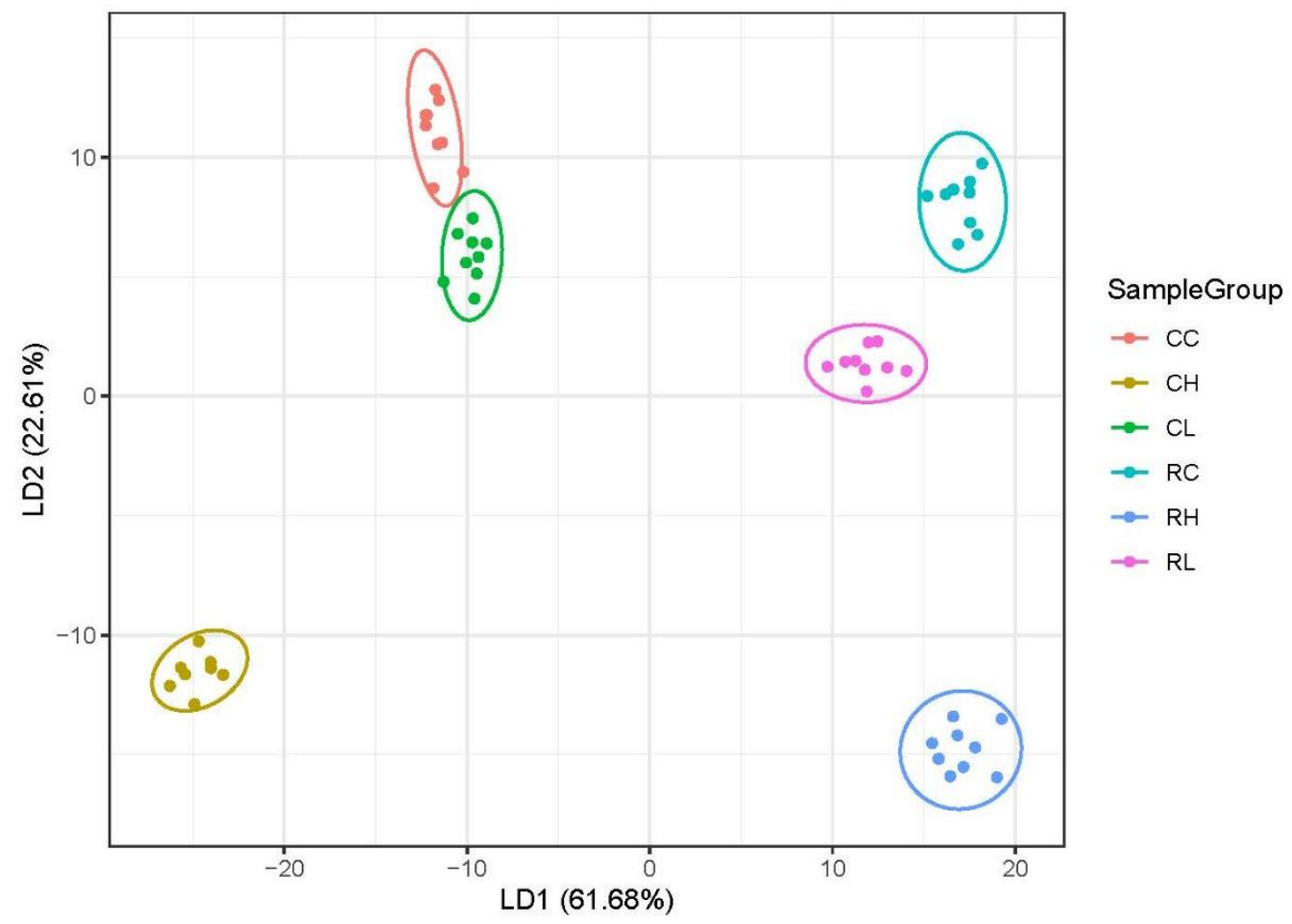

Figure 4. Linear discriminant analysis of Pinot noir wines by winemaking conditions with 25 selected important variables out of 243 lipid species as dependent variables and six winemaking conditions as independent variables. (RC: $27^{\circ} \mathrm{C}$ fermentation temperature, $0 \mathrm{~g} / \mathrm{L}$ yeast product addition; RL: $27^{\circ} \mathrm{C}$ fermentation temperature, $0.5 \mathrm{~g} / \mathrm{L}$ yeast product addition; $\mathrm{RH}: 27^{\circ} \mathrm{C}$ fermentation temperature, $1 \mathrm{~g} / \mathrm{L}$ yeast product addition; $\mathrm{CC}: 16^{\circ} \mathrm{C}$ fermentation temperature, $0 \mathrm{~g} / \mathrm{L}$ yeast product addition; $\mathrm{CL}: 16{ }^{\circ} \mathrm{C}$ fermentation temperature, $0.5 \mathrm{~g} / \mathrm{L}$ yeast product addition; and $\mathrm{CH}$ : $16{ }^{\circ} \mathrm{C}$ fermentation temperature, $1 \mathrm{~g} / \mathrm{L}$ yeast product addition).

Using random forest analysis, the most important lipidomic features were extracted, with 25 lipid compounds being the most important for explaining the differences based on fermentation temperature and yeast product addition (Figure 5). Lipids were ranked based on their importance in wine treatment separation. They showed relatively $0 \%$ OOB compared to other models (Table S4). The $\mathrm{CH}$ wines had relatively higher amounts of lipids compared to the wines from other treatments, mostly FFA, DG and TG. The majority of lipids in $\mathrm{CH}$ have relative concentrations higher than 1 (represented as the yellow boxes in Figure 5). Wines made under other treatments did not have many lipids at high relative concentrations. CC and CL wines had the lowest relative amount of lipids, while RC, RH and RL wines had higher relative amounts.

An untargeted lipidomic approach was successfully used to identify the most important lipids in differentiating the wine treatments. FFA, AC, DG and TG are the main lipid classes contributing to the differences. The effects of yeast product addition on the relative concentration of the 25 important lipids are noted in Figure 5. Adding more yeast product altered the lipidomic profile of the wines, even though it did not increase the amount of total lipids. The $\mathrm{CH}$ and $\mathrm{RH}$ wines were distinctively separated from other groups (Figure 5). In the cold fermentation groups (CC, $\mathrm{CL}$ and $\mathrm{CH}$ ), the relative concentration of lipids in $\mathrm{CH}$ were seen to be much higher. Similar trends were also observed in the high fermentation temperature groups.

\subsection{Sensory-Descriptive Analysis}

Two-way ANOVA showed significant differences in sweetness and drying among wine treatments having different fermentation temperatures ( $p$-value $=0.004$ for drying and 0.005 for sweetness, Table S5). The sweetness taste attribute was higher in wines fermented 
at $16^{\circ} \mathrm{C}$ compared to those fermented at $27^{\circ} \mathrm{C}$ (Figure 6). The drying mouthfeel attribute was rated with significantly lower intensity in wines fermented at $16^{\circ} \mathrm{C}$ compared to wines fermented at $27^{\circ} \mathrm{C}$ (Figure 6). Descriptive analysis of wine samples showed no significant differences for acidity, astringency, bitterness, viscosity and warmth. It is worth considering that the mean intensity rating of astringency was higher in RL wines compared to other treatments, and viscosity and warmth had the highest mean intensity rating in CC.
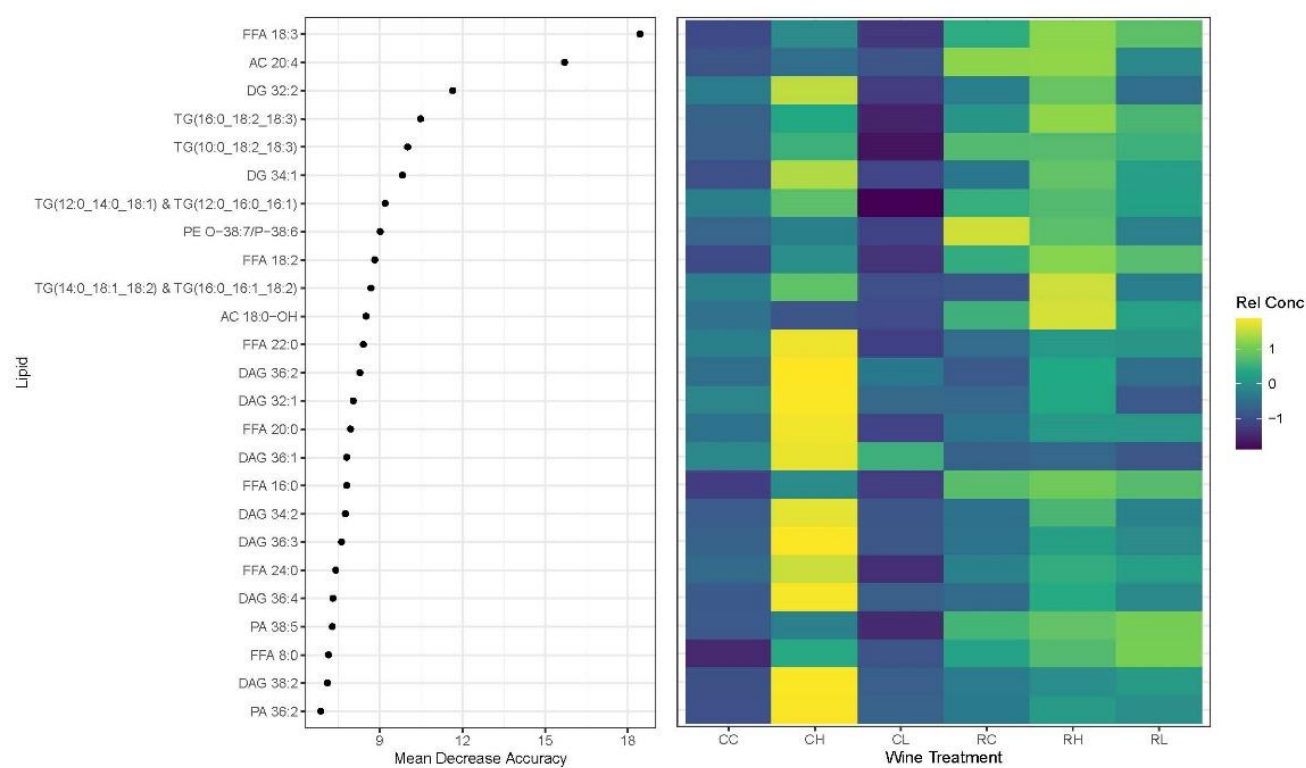

Figure 5. Variance of importance plot (VIP) for lipids that contribute the greatest variance to the classification of six wine treatments. Relative concentrations (Rel Conc) for each group are also shown (yellow for higher concentrations, dark green for lower).

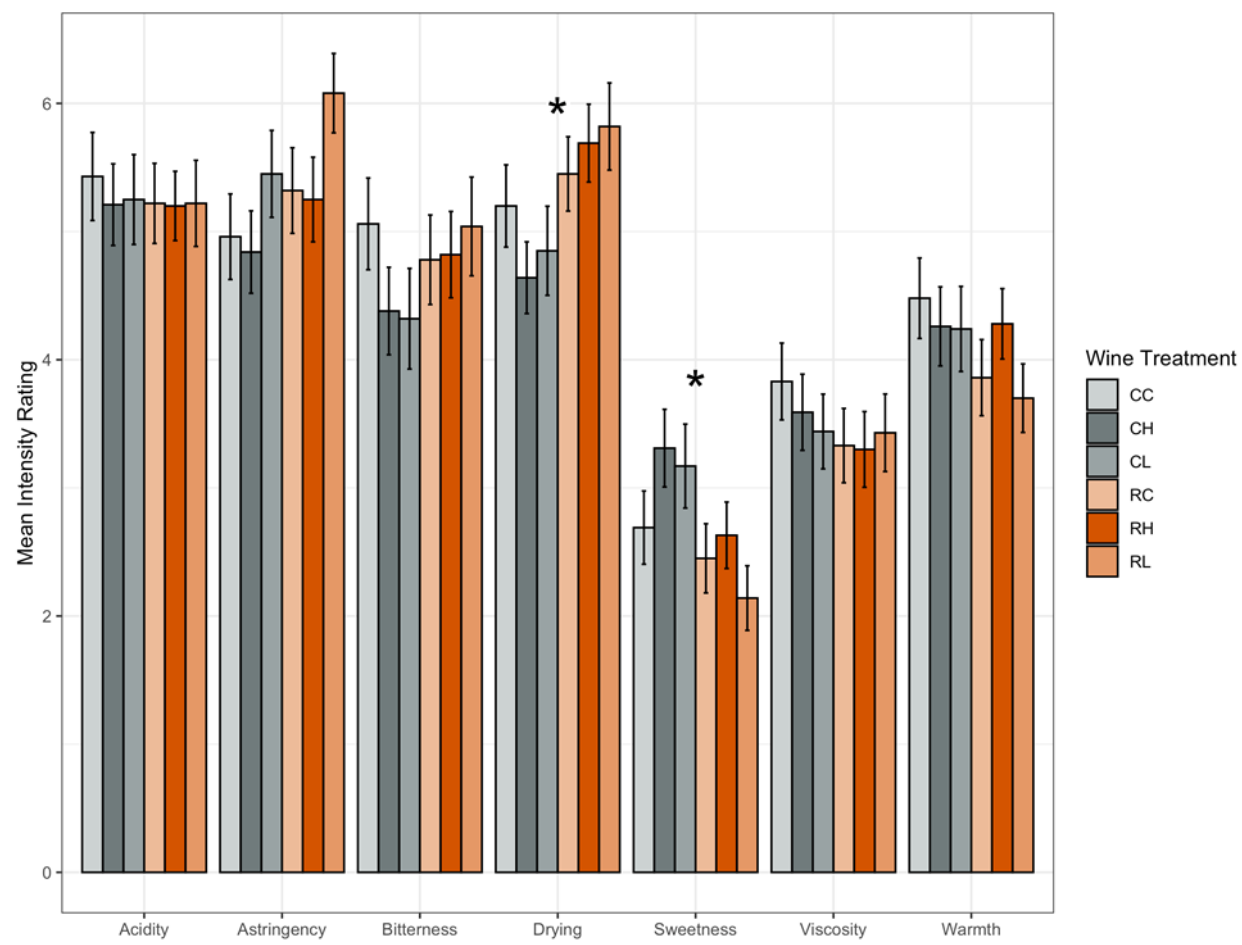

Figure 6. Mean perceived intensity rating (mean \pm standard error) for taste and mouthfeel attributes in descriptive analysis test of wine treatments. * indicates significant difference (two-way ANOVA, $\alpha=0.05)$. 


\subsection{Sensory-CATA}

CATA data for taste and mouthfeel descriptors show variations in taste and mouthfeel terms associated with wine treatments. Across the first two dimensions, $77.3 \%$ variance was found. Wines fermented at $16^{\circ} \mathrm{C}(\mathrm{CC}, \mathrm{CL}$, and $\mathrm{CH})$ were described as oily, velvety, and soft. Wines fermented at $27^{\circ} \mathrm{C}(\mathrm{RC}, \mathrm{RL}$ and $\mathrm{RH})$ were described as grainy, gummy, harsh, unripe and sticky (Figure 7).

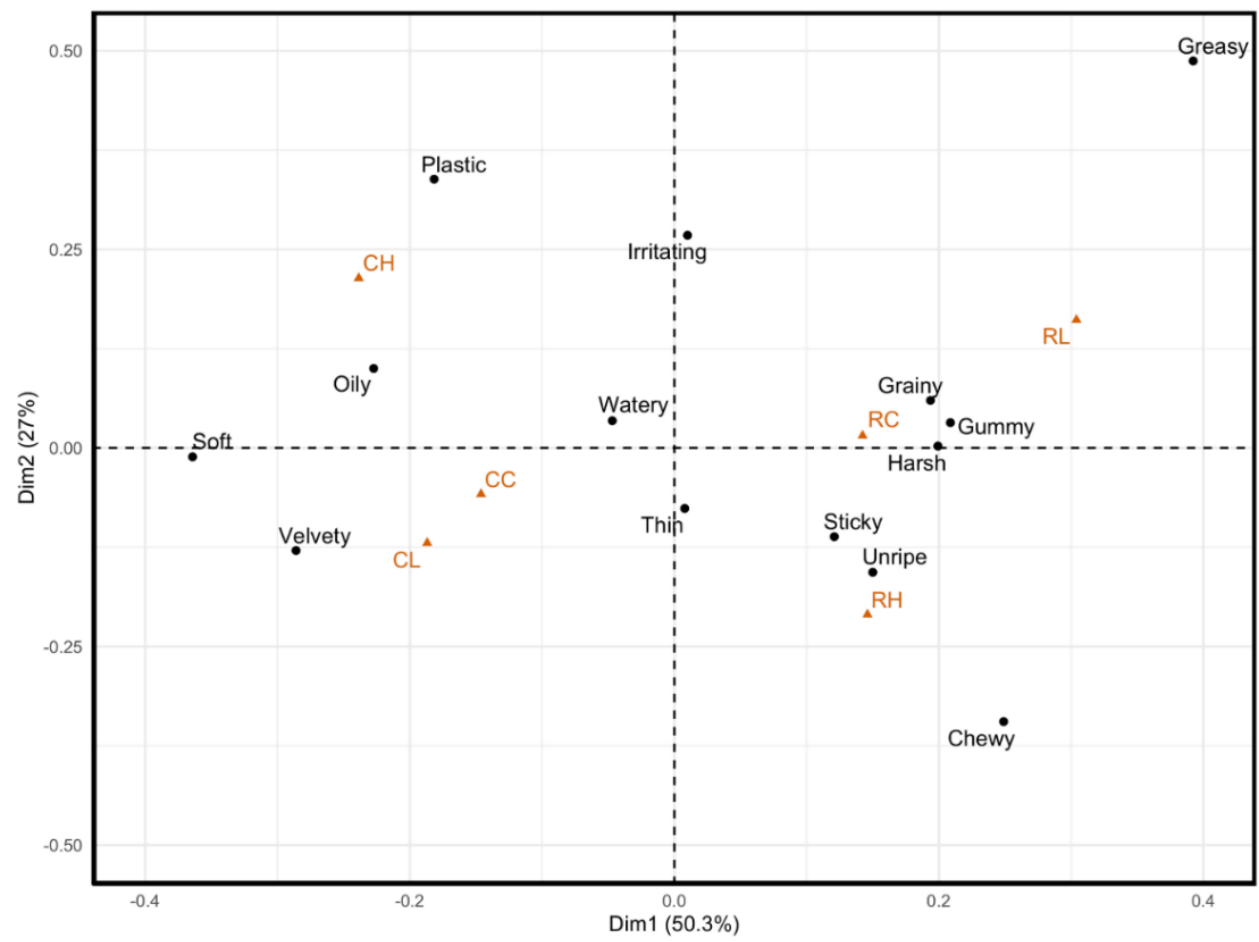

Figure 7. Corresponding analysis using CATA data. CATA terms are in black and wine treatments are in orange.

\section{Discussion}

4.1. Impacts of Yeast Fermentation Temperature on Wine Lipids, Taste and Mouthfeel Perception

Fermentation temperature has a significant effect on grape extraction [16]. A higher lipid concentration in a high temperature fermentation wine could be due to a greater breakdown of the grape firm tissues and the yeast cell wall during fermentation [16]. It would be of interest to determine the source of lipid differences in the present study treatments to establish if lipid extraction was from both or one specific source.

Increasing fermentation temperature produces wine with higher phenolics and color [42,43]. Our total phenolic data confirmed this finding, as the higher fermentation temperature resulted in wines with greater phenolics (Table 2). Phenolics, especially polymeric flavanols, are known to have major impacts on wine taste and mouthfeel $[10,16,44]$. Wines with higher phenolic content are known to have more intense bitterness, astringency, drying and sourness [44]. Among the seven attributes assessed in the descriptive analysis test, some were expected to show significant differences between wines fermented at $16^{\circ} \mathrm{C}$ and $27^{\circ} \mathrm{C}$. However, drying was the only mouthfeel attribute that was significantly more intense in high fermentation temperature wines and sweetness was the only taste attribute that was significantly less intense in high fermentation temperature wines (Figure 6).

Wine fermented at $27^{\circ} \mathrm{C}$ had significantly lower alcohol content and lower sweetness perception. Sweetness is the sensory attribute found to be significantly different and is not known to be impacted by lipids (Figure 5). It is known that high alcohol content can affect sweetness perception in wine [45]. The higher temperature used in the present study 
may have evaporated a portion of the ethanol content, resulting in a significant change of sweetness or may also be due to fermentation yield.

Fermentation temperature did not have strong impacts on bitterness, astringency, acidity, viscosity and warmth attributes in this study. Even though there was a significantly higher amount of phenolics in wines fermented at $27^{\circ} \mathrm{C}$, the impacts of phenolics on wine taste and mouthfeel may be masked by the presence of wine lipids, as lipids have been found to reduce the astringency in wine [46], although the concentration of lipids studied were much higher than those tested in our study. Research has examined the effects of phenolic compounds on lipid models in oral cell membranes and lipid droplets found in food [6]. Interactions between catechin, epicatechin and epigallocatechin gallate and lipids were examined and strong interactions were found between phenolics, especially tannins, and lipids in a model system [6]. The authors stated that astringency could be affected by potential competition between the tannin-lipid and other tannin-macromolecule interactions [47]. Similar interactions could be found in the present study treatments but further research is needed to confirm this. One of the difficulties of working in a wine system is that it is difficult to isolate the exact impact of lipids to wine mouthfeel. Working with a simpler model and adding different wine components may be a way to isolate any sensory changes specifically imparted by lipids, such as those conducted in Phan et Siebert [7].

\subsection{Impacts of Yeast Product Addition on Wine Lipids, Taste and Mouthfeel Perception}

Theoretically, the addition of yeast products after fermentation would be similar to having more yeast cells during fermentation and was predicted to increase the total lipids. However, yeast product addition did not have significant effects on the total lipid concentration (Figure 2). Yeast product did alter the wine lipidomic profiles but may not be a good source for enhancing total lipid content in wine. The impact of different lipids to wine sensory are discussed further in Section 4.3.

Adding yeast product had significant impacts on total phenolics. The total phenolics decreased in wines with higher yeast additions (Table 2). A similar argument can be made in high fermentation wine; since there were more organic substances present in high yeast product addition wine, there could be more chance for phenolics to interact with the components, such as lipids, polysaccharides, and proteins, to form entanglement and then precipitate out of the solution [48]. As a result, the contribution of phenolics to taste and mouthfeel perception was insignificant in wines with yeast product addition.

Astringency is a very important quality factor that influences consumer preference [49]. A recent study reported that increasing astringency decreased liking and elicited more intense negative emotions in wine consumers [4]. A combination of $27^{\circ} \mathrm{C}$ fermentation and low $(0.5 \mathrm{~g} / \mathrm{L})$ addition of yeast product as in RL treatment would potentially provide higher astringency mouthfeel thus an undesirable sensory outcome. It is therefore possible to craft a wine with more desirable mouthfeel by altering fermentation temperature and use of yeast product addition.

\subsection{Impacts of Wine Lipids on Taste and Mouthfeel Perception}

Research has shown that dietary lipids interact with wine phenolics to form wine phenolic-lipid complexes at molecular levels. Wine phenolics interact with the lipid systems, multilamellar vesicles, isotropic bicelles or lipid droplets from a phospholipidstabilized oil-in-water emulsion $[6,46]$. Further investigation focusing on lipid systems present in wine would provide more information about how wine lipids interact with phenolic compounds. The interactions could potentially lead to a decrease in astringency perception in phenolic solutions [46]. The result was not observed in this study. Lipids found in Pinot noir wine did not have an effect on astringency. Astringency perception was not significantly different among wines with higher total lipids. The previous studies investigating dietary lipids found in fatty food or oil so the lipids were at higher concentrations compared to the normal lipid concentration found in wine. This could be possible 
because the wine lipid content was low in general and those wine treatments with high lipid content also had higher concentrations of phenolics.

The freer fatty acids in the cooler fermentation wines might be the cause of the significant increase in TA and lower $\mathrm{pH}$ in these wines (Table 2). Differences in wine lipidomic profiles may be driving the differences in sensory perception seen in CATA results (Figure 6). $\mathrm{CH}$ wine with a higher relative concentration of FFA, PA and DG was associated with mouthfeel terms, such as oily, soft and velvety. FFA lipids were one of the most important lipid classes based on treatments as determined by random forest (specifically, unsaturated FFA 18:3 and FFA 18:2 and the saturated FFA 22:0, FFA 20:0, FFA 8:0, FFA 16:0 and FFA 24:0). FFA lipids found to be different between the wine treatments have been reported as major FFAs in grapes and wine [10]. In addition, FFAs have been considered the main component related to fat taste [50]. Specifically, the longer and more saturated the fatty acids, the greater the contribution to smoother and creamier mouthfeel texture [51]. Fatty acids have also been found to modulate bitter taste in aqueous solutions [52]. Besnard et al. (2016) and Mattes (2009) both agreed that long-chain fatty acids are indeed an orosensory effective taste stimuli [53,54].

Viscosity was not affected by either fermentation temperature or yeast product addition. Sugar has been reported to have influence on viscosity perception [45]. The glucose and fructose content were not changed among wine treatments. The insignificant changes in viscosity perception is aligned with previous sensory work [7]. When low levels of lipids are present, phospholipids appear to be a factor driving viscosity perception. The wine treatments produced in this study did not utilize phospholipids, as these lipids were not found to be important in treatment differentiation (Figure 5). The lack of phospholipids additions to the wines is the most likely explanation for the lack of viscosity changes seen.

\section{Conclusions}

This work is one of the first to evaluate lipid composition in Pinot noir wine and its impact to taste and mouthfeel perception. Our study showed that fermentation temperature is an important factor that influences the concentrations of several wine chemical components and wine taste and mouthfeel characteristics. By increasing the fermentation temperature, the total lipids increased significantly and wine taste and mouthfeel had lower sweetness and higher drying intensities. Adding yeast product additions to a winemaking procedure can change the Pinot noir wine lipidomic profile but did not affect the total lipids or wine sensory. Interactions between the two winemaking factors only influenced the variations in wine basic components but had no impact on the total lipids nor wine sensory. Lipid compositions of wines made under different conditions show clear distinctions among wine treatments. The differences in lipid profiles of Pinot noir wine treatments suggest potential impacts of winemaking techniques on the composition of lipids and wine taste and mouthfeel perception profiles. There were distinctive groups of taste and mouthfeel terms associated with each wine treatment. Specifically, the fermentation temperature is more important than yeast product addition to alter the sweetness and drying properties of the wine. This information may be used to develop winemaking practices that produce wine with desirable taste and mouthfeel attributes, attributed to altering lipid composition.

Supplementary Materials: The following are available online at https:/ / www.mdpi.com/article/ 10.3390/horticulturae8010052/s1, Table S1: Mean basic chemistry \pm SE with $p$-values of two-way ANOVA and Tukey's HSD for the main effects, Table S2: $p$-values of two-way ANOVA for mean peak intensity of 233 lipid compounds. Table S3: Peak intensities of lipid compounds detected in Pinot noir wine samples from different wine treatments. Table S4: Percent out-of-bag (\% OOB) \pm standard deviation of lipid combination models, Table S5: $p$-values of the two-way ANOVA of the descriptive analysis of the wine treatments. Figure S1: Temperature and ${ }^{\circ}$ Brix of wine treatment tanks during alcoholic fermentation.

Author Contributions: Conceptualization, Q.P. and E.T.; methodology, Q.P, A.D., J.O. and E.T.; software, Q.P.; validation, Q.P. and E.T.; formal analysis, Q.P. and E.T.; investigation, Q.P. and E.T.; 
resources, E.T.; data curation, Q.P.; writing—original draft preparation, Q.P.; writing-review and editing, E.T., A.D. and J.O.; visualization, Q.P.; supervision, E.T.; project administration, E.T.; funding acquisition, E.T. All authors have read and agreed to the published version of the manuscript.

Funding: This research was funded by E \& J Gallo Winery.

Institutional Review Board Statement: The study was conducted according to the guidelines of the Declaration of Helsinki and approved by the Institutional Review Board (or Ethics Committee) of Oregon State University (Corvallis, OR, USA), protocol code IRB-2020-0610 and Date of approval: 3 June 2020.

Informed Consent Statement: Informed consent was obtained from all subjects involved in the study.

Acknowledgments: The authors thank the Mass Spectrometry Center at Oregon State University for assisting the lipidomic analysis.

Conflicts of Interest: The authors declare no conflict of interest.

\section{References}

1. Bertino, M.; Lawless, H.T. Understanding Mouthfeel Attributes: A Multidimensional Scaling Approach. J. Sens. Stud. 1993, 8, 101-114. [CrossRef]

2. Cosme, F.; Vilela, A.; Jordão, A.M.; Desk, S. Wine Phenolics: Looking for a Smooth Mouthfeel. J. Food Sci. Technol. 2016, 1, 20-28.

3. Laguna, L.; Bartolomé, B.; Moreno-Arribas, M.V. Mouthfeel Perception of Wine: Oral Physiology, Components and Instrumental Characterization. Trends Food Sci. Technol. 2017, 59, 49-59. [CrossRef]

4. Niimi, J.; Danner, L.; Li, L.; Bossan, H.; Bastian, S.E.P. Wine Consumers' Subjective Responses to Wine Mouthfeel and Understanding of Wine Body. Food Res. Int. 2017, 99, 115-122. [CrossRef]

5. Runnebaum, R.C.; Boulton, R.B.; Powell, R.L.; Heymann, H. Key Constituents Affecting Wine Body-An Exploratory Study. J. Sens. Stud. 2011, 26, 62-70. [CrossRef]

6. Furlan, A.L.; Castets, A.; Nallet, F.; Pianet, I.; Grélard, A.; Dufourc, E.J.; Géan, J. Red Wine Tannins Fluidify and Precipitate Lipid Liposomes and Bicelles. A Role for Lipids in Wine Tasting? Langmuir 2014, 30, 5518-5526. [CrossRef]

7. Phan, Q.; Hoffman, S.; Tomasino, E. Contribution of Lipids to Taste and Mouthfeel Perception in a Model Wine Solution. ACS Food Sci. Technol. 2021, 1, 1561-1566. [CrossRef]

8. Jackson, R.S. Wine Tasting: A Professional Handbook; Academic Press: San Diego, CA, USA, 2016; ISBN 978-0-12-801826-2.

9. Phan, Q.; Tomasino, E. Untargeted Lipidomic Approach in Studying Pinot Noir Wine Lipids and Predicting Wine Origin. Food Chem. 2021, 355, 129409. [CrossRef] [PubMed]

10. Waterhouse, A.L.; Sacks, G.L.; Jeffery, D.W. Understanding Wine Chemistry; John Wiley \& Sons, Inc.: West Sussex, UK, 2016; ISBN 978-1-118-62780-8.

11. Harbertson, J.F.; Hodgins, R.E.; Thurston, L.N.; Schaffer, L.J.; Reid, M.S.; Landon, J.L.; Ross, C.F.; Adams, D.O. Variability of Tannin Concentration in Red Wines. Am. J. Enol. Vitic. 2008, 59, 210-214.

12. Vidal, S.; Courcoux, P.; Francis, L.; Kwiatkowski, M.; Gawel, R.; Williams, P.; Waters, E.; Cheynier, V. Use of an Experimental Design Approach for Evaluation of Key Wine Components on Mouth-Feel Perception. Food Qual. Prefer. 2004, 15, 209-217. [CrossRef]

13. Woody, R.C.; Schmidt, R. Following the Roots of Oregon Wine. Or. Hist. Q. 2013, 114, 324-339. [CrossRef]

14. Li, S.; Bindon, K.; Bastian, S.E.P.; Jiranek, V.; Wilkinson, K.L. Use of Winemaking Supplements to Modify the Composition and Sensory Properties of Shiraz Wine. J. Agric. Food Chem. 2017, 65, 1353-1364. [CrossRef] [PubMed]

15. Dequin, S.; Escudier, J.-L.; Bely, M.; Noble, J.; Albertin, W.; Masneuf-Pomarède, I.; Marullo, P.; Salmon, J.-M.; Sablayrolles, J.M. How to Adapt Winemaking Practices to Modified Grape Composition under Climate Change Conditions. OENO One 2017, 51, 205-214. [CrossRef]

16. Sacchi, K.L.; Bisson, L.F.; Adams, D.O. A Review of the Effect of Winemaking Techniques on Phenolic Extraction in Red Wines. Am. J. Enol. Vitic. 2005, 56, 197-206.

17. Unterkofler, J.; Muhlack, R.A.; Jeffery, D.W. Processes and Purposes of Extraction of Grape Components during Winemaking: Current State and Perspectives. Appl. Microbiol. Biotechnol. 2020, 104, 4737-4755. [CrossRef]

18. Hunter, K.; Rose, A.H. Lipid Composition of Saccharomyces Cerevisiae as Influenced by Growth Temperature. Biochim. Biophys. Acta (BBA) Lipids Lipid Metab. 1972, 260, 639-653. [CrossRef]

19. Coleman, M.C.; Fish, R.; Block, D.E. Temperature-Dependent Kinetic Model for Nitrogen-Limited Wine Fermentations. Appl. Environ. Microbiol. 2007, 73, 5875-5884. [CrossRef]

20. Henderson, C.M.; Block, D.E. Examining the Role of Membrane Lipid Composition in Determining the Ethanol Tolerance of Saccharomyces Cerevisiae. Appl. Environ. Microbiol. 2014, 80, 2966-2972. [CrossRef]

21. Gil-Muñoz, R.; Moreno-Pérez, A.; Vila-López, R.; Fernández-Fernández, J.I.; Martínez-Cutillas, A.; Gómez-Plaza, E. Influence of Low Temperature Prefermentative Techniques on Chromatic and Phenolic Characteristics of Syrah and Cabernet Sauvignon Wines. Eur. Food Res. Technol. 2009, 228, 777-788. [CrossRef] 
22. Reynolds, A.; Cliff, M.; Girard, B.; Kopp, T.G. Influence of Fermentation Temperature on Composition and Sensory Properties of Semillon and Shiraz Wines. Am. J. Enol. Vitic. 2001, 52, 235-240.

23. Ndlovu, T.; Divol, B.; Bauer, F.F. Yeast Cell Wall Chitin Reduces Wine Haze Formation. Appl. Environ. Microbiol. 2018, 84, e00668-18. [CrossRef]

24. Ángeles Pozo-Bayón, M.; Andújar-Ortiz, I.; Moreno-Arribas, M.V. Scientific Evidences beyond the Application of Inactive Dry Yeast Preparations in Winemaking. Food Res. Int. 2009, 42, 754-761. [CrossRef]

25. Aguilar-Uscanga, B.; François, J.M. A Study of the Yeast Cell Wall Composition and Structure in Response to Growth Conditions and Mode of Cultivation. Lett. Appl. Microbiol. 2003, 37, 268-274. [CrossRef]

26. Rattray, J.B.; Schibeci, A.; Kidby, D.K. Lipids of Yeasts. Bacteriol. Rev. 1975, 39, 197-231. [CrossRef] [PubMed]

27. Sáenz-Navajas, M.-P.; Ferreira, V.; Dizy, M.; Fernández-Zurbano, P. Characterization of Taste-Active Fractions in Red Wine Combining HPLC Fractionation, Sensory Analysis and Ultra Performance Liquid Chromatography Coupled with Mass Spectrometry Detection. Anal. Chim. Acta 2010, 673, 151-159. [CrossRef] [PubMed]

28. Iland, P. Chemical Analysis of Grapes and Wine; Patrick Iland Wine Promotions PTYLTD: Adelaide, Australia, 2004; ISBN 978-0-9581605-1-3.

29. Gallander, J.; Briner, L.; Stetson, J.; Liu, J.-W.; Krielow, L.; Wilker, K.; Romberger, R.; Stamp, C.; Riesen, R. Manual for Wine Analysis and Laboratory Techniques; Ohio State University, OARDC: Wooster, OH, USA, 1991.

30. Waterhouse, A.L. Determination of Total Phenolics. Curr. Protoc. Food Anal. Chem. 2002, 6, I1.1.1-I1.1.8. [CrossRef]

31. Choi, J.; Leonard, S.W.; Kasper, K.; McDougall, M.; Stevens, J.F.; Tanguay, R.L.; Traber, M.G. Novel Function of Vitamin E in Regulation of Zebrafish (Danio Rerio) Brain Lysophospholipids Discovered Using Lipidomics. J. Lipid Res. 2015, 56, 1182-1190. [CrossRef]

32. Definition of SWEET. Available online: https://www.merriam-webster.com/dictionary/sweet (accessed on 28 July 2021 ).

33. Sparrow, A.M.; Holt, H.E.; Pearson, W.; Dambergs, R.G.; Close, D.C. Accentuated Cut Edges (ACE): Effects of Skin Fragmentation on the Composition and Sensory Attributes of Pinot Noir Wines. Am. J. Enol. Vitic. 2016, 67, 169-178. [CrossRef]

34. Williamson, P. Sensory Descriptive Analysis on Commercial Wines of Varied Styles; The Australian Wine Research Institute: Urrbrae, Australia, 2013.

35. Gawel, R.; Oberholster, A.; Francis, I.L. A 'Mouth-Feel Wheel': Terminology for Communicating the Mouth-Feel Characteristics of Red Wine. Aust. J. Grape Wine Res. 2000, 6, 203-207. [CrossRef]

36. Guinard, J.-X.; Mazzucchelli, R. The Sensory Perception of Texture and Mouthfeel. Trends Food Sci. Technol. 1996, 7, 213-219. [CrossRef]

37. R Core Team. R: A Language and Environment for Statistical Computing; R Foundation for Statistical Computing: Vienna, Austria, 2021.

38. Wickham, H. Ggplot2: Elegant Graphics for Data Analysis; Springer: New York, NY, USA, 2016; ISBN 978-3-319-24277-4.

39. Campo, E.; Ballester, J.; Langlois, J.; Dacremont, C.; Valentin, D. Comparison of Conventional Descriptive Analysis and a Citation Frequency-Based Descriptive Method for Odor Profiling: An Application to Burgundy Pinot Noir Wines. Food Qual. Prefer. 2010, 21, 44-55. [CrossRef]

40. Lê, S.; Josse, J.; Husson, F. FactoMineR: An R Package for Multivariate Analysis. J. Stat. Softw. 2008, 25, 1-18. [CrossRef]

41. Kassambara, A.; Mundt, F. Factoextra: Extract and Visualize the Results of Multivariate Data Analyses; 2020. Available online: https:/ / cran.r-project.org/web/packages/factoextra/readme/README.html (accessed on 18 January 2021).

42. Gao, L.; Girard, B.; Mazza, G.; Reynolds, A.G. Changes in Anthocyanins and Color Characteristics of Pinot Noir Wines during Different Vinification Processes. J. Agric. Food Chem. 1997, 45, 2003-2008. [CrossRef]

43. Girard, B.; Yuksel, D.; Cliff, M.A.; Delaquis, P.; Reynolds, A.G. Vinification Effects on the Sensory, Colour and GC Profiles of Pinot Noir Wines from British Columbia. Food Res. Int. 2001, 34, 483-499. [CrossRef]

44. Frost, S.C.; Harbertson, J.F.; Heymann, H. A Full Factorial Study on the Effect of Tannins, Acidity, and Ethanol on the Temporal Perception of Taste and Mouthfeel in Red Wine. Food Qual. Prefer. 2017, 62, 1-7. [CrossRef]

45. Nurgel, C.; Pickering, G. Contribution of Glycerol, Ethanol and Sugar to the Perception of Viscosity and Density Elicited by Model White Wines. J. Texture Stud. 2005, 36, 303-323. [CrossRef]

46. Saad, A.; Bousquet, J.; Fernandez-Castro, N.; Loquet, A.; Géan, J. New Insights into Wine Taste: Impact of Dietary Lipids on Sensory Perceptions of Grape Tannins. J. Agric. Food Chem. 2021, 69, 3165-3174. [CrossRef]

47. Furlan, A.L.; Saad, A.; Dufourc, E.J.; Géan, J. Grape Tannin Catechin and Ethanol Fluidify Oral Membrane Mimics Containing Moderate Amounts of Cholesterol: Implications on Wine Tasting? Biochimie 2016, 130, 41-48. [CrossRef]

48. Scollary, G.R.; Pásti, G.; Kállay, M.; Blackman, J.; Clark, A.C. Astringency Response of Red Wines: Potential Role of Molecular Assembly. Trends Food Sci. Technol. 2012, 27, 25-36. [CrossRef]

49. Bajec, M.R.; Pickering, G.J. Astringency: Mechanisms and Perception. Crit. Rev. Food Sci. Nutr. 2008, 48, 858-875. [CrossRef]

50. Martin, C.; Passilly-Degrace, P.; Gaillard, D.; Merlin, J.; Chevrot, M.; Besnard, P. The Lipid-Sensor Candidates CD36 and GPR120 Are Differentially Regulated by Dietary Lipids in Mouse Taste Buds: Impact on Spontaneous Fat Preference. PLoS ONE 2011, 6, e24014. [CrossRef] [PubMed]

51. Zhou, X.; Shen, Y.; Parker, J.K.; Kennedy, O.B.; Methven, L. Relative Effects of Sensory Modalities and Importance of Fatty Acid Sensitivity on Fat Perception in a Real Food Model. Chem. Percept. 2016, 9, 105-119. [CrossRef] [PubMed] 
52. Aglione, A.; Cassutt, K.; Dragan, S.; Gravina, S.; Kurash, Y.; Johnson, W. Modulation of Bitterness and Mouthfeel via Synergistic Mixtures of Long Chain Fatty Acids. U.S. Patent Application No. 15/106,179, 3 November 2016.

53. Besnard, P.; Passilly-Degrace, P.; Khan, N.A. Taste of Fat: A Sixth Taste Modality? Physiol. Rev. 2016, 96, 151-176. [CrossRef] [PubMed]

54. Mattes, R.D. Is There a Fatty Acid Taste? Annu. Rev. Nutr. 2009, 29, 305-327. [CrossRef] 